\title{
Triratna Budistlik Kogukond: juhtumiuuring budistlikust kogudusest Eestis ${ }^{1}$
}

\begin{abstract}
Lauri Liiders
Teesid: Tegu on esimese juhtumiuuringuga Eestis tegutsevast budistlikust kogudusest. Triratna Budistlik Kogukond on Läänes rajatud oikumeeniline budistlik organisatsioon, mille eesmärk on koondada teatud õpetuslikke ja harjutuslikke elemente erinevatest traditsioonilistest budistlikest koolkondadest ja esitada neid Euroopa kultuuriruumile mõistetavas vormis. Seda võib vaadelda osana Lääne idastumise protsessist, mille käigus üritatakse kohandada traditsioonilisi budistlikke õpetusi siinsete harjutajate vajadustele. Keskendun ühele budistlikule kogudusele ning püüan kirjeldada selle ajalugu Eestis ja välismaal, samuti uurida selle liikmete tegevust, uskumusi, vaateid ja religioosseid praktikaid.
\end{abstract}

Märksõnad: budism, Eesti, religioossed praktikad, usundiuurimine

\section{Sissejuhatus}

Käesolev artikkel keskendub rahvusvahelise oikumeenilise budistliku organisatsiooni Friends of Western Buddhist Order ehk Lääne Budistliku Vennaskonna Sõbrad (lühendatult FWBO) tegevusele Eestis. 1967. aastal Suurbritannias rajatud FWBO käsitleb oma tegevuse algusena Eestis aastat 1989. FWBO kohalik kogudus on oma õpetustegevuses olnud sõltuv eelkõige Lääne Budistliku Vennaskonna (Western Buddhist Order, ehk lühendatult WBO) liikmetest, kes on käinud Eestis õpetamas peamiselt Soomest ja Suurbritanniast. Oma tegevuse jooksul on kogudus end tähistanud mitme nimega: Eesti Lääne Budistliku Vennaskonna Sõbrad, Eesti FWBO, Budakoda, Sulevimäe Budakoda. Kuna rahvusvaheline organisatsioon muutis oma nime 2010. aastal Triratna Budistlikuks Kogukonnaks (Triratna Buddhist Community), on viimastel aastatel hakatud kasutama eelkõige viimatimainitud nime. Alates 2012. aastast kannab 2002. aastal mittetulundusühinguna registreeritud Eesti Lääne Budistliku Vennaskonna Sõbrad nime Budakoda. Sama nime kasutatakse ka ühingu kodulehel ning see seondub liikumise püsiva asukohaga Tallinnas aadressil Luha tn 1. 
Vaatlen lääneriigis alguse saanud budistlikku organisatsiooni osana Lääne idastumise protsessist, mille käigus üritatakse kohandada traditsioonilisi budistlikke õpetusi siinsete harjutajate vajadustele. Lääne idastumisele omaseid suundumusi on Eesti religioonisotsioloogilistes uuringutes varem käsitlenud Lea Altnurme, kes toob välja, et Lääne lunastusõpetus on asendumas vaimse täiustumise õpetusega, mille eesmärgiks võib olla ka budistlik virgumine. Altnurme toob selle juures välja kaks asjaolu: Idast võetakse üle vaid uuele elutundele omased ideed; ülevõetud ideed on läänestunud. Budismi puhul tähendab see, et kõik, mis meenutab vana monoteistlikku mudelit, näiteks puhta maa traditsioonile omane Buddha Āmitabha austamine palvete kordamise kaudu, jäetakse kõrvale (Altnurme 2006: 46).

Käesoleva artikli aluseks on minu Tartu Ülikooli usuteaduskonnas 2012. aastal religiooniantropoloogia erialal kaitstud magistritöö "Budism uususundina Eestis Triratna Budistliku kogukonna näitel” (Liiders 2012a). Valdav osa töö koostamiseks vajalikust materjalist on kogutud väliuuringute käigus, milleks olid eelkõige intervjuud Budakojas ja Tartu Triratna grupis, küsitlused ja suulise ajaloo kogumine. Lisaks sooritasin aastatel 2011-2013 Tallinnas, Tartus, Põlvamaal ja Soomes Läyliäise lähedal Abhayaloka (budistide enda pandud nimi) 31 ürituse osalusvaatlust (54 päeva).

Äärmiselt väärtuslik kirjalik allikas Eesti Triratna ajaloo koostamisel aastate 1989-2002 kohta oli Triratna ordineeritud liikme Tiia Lõokese koostatud FWBO ürituste loetelu, kus on ära märgitud ürituste toimumiste kuupäevad, läbiviijad ning enamasti ka asukoht, ühtlasi on üritust lühidalt kirjeldatud nii eesti kui ka inglise keeles. Olen sellele tekstis viidanud, kui info konkreetse ürituse või fakti kohta pärineb ainult sealt.

Eesti FWBOd on akadeemilises plaanis varem käsitlenud Britt-Maria Preemi ja Ave Põleniku 2001. aastast pärinev bakalaureusetöö "Budistlikud kogudused Eestis 1984-2001", mis kaitsti Tartu Ülikooli usuteaduskonnas. Selle bakalaureusetöö põhjal on koostatud ka Ave Põleniku kirjutatud peatükk "Budismist Eestis" raamatus Mitut usku Eesti (TÜ kirjastus, 2004). Eesti Triratna kohta on ilmunud siinkirjutaja koostatud peatükk "Triratna Budistlik Kogukond" kogumikus Uued usulised ja vaimsed ühendused Eestis (TÜ kirjastus, 2012), kus käsitlen lühidalt organisatsiooni ajaloolist arengut siin ja välismaal ning peamisi usulisi praktikaid.

Kuna minule teadaolevalt pole Eestis varem budistlike koguduste kohta tehtud süvitsiminevaid juhtumiuuringuid, loodan, et käesolev uurimus osutub kasulikuks Eesti religiooniloo tulevastele uurijatele. 


\section{Triratna Budistliku Kogukonna ajalugu välismaal}

FWBO rajaja Dennis Lingwood sündis Londonis 1925. aastal. Budismi vastu hakkas ta tõsisemalt huvi tundma 16aastaselt pärast Teemantsuutra lugemist. Teise maailmasõja ajal osales ta aktiivselt Londoni piiratud ulatusega budistlikus tegevuses. Hiljem siirdus ta aega teenima Kaug-Itta ning jäi pärast sõda elama Indiasse.

Lingwood, kes hakkas pärast mungaks saamist kasutama nime Sangharakshita, õppis üle kahekümne aasta Indias erinevate õpetajate käe all, saades esmalt mungapühitsuse Sarnathis theravaada traditsioonis 1950. aastal, kuid keskendudes hiljem Põhja-Indiasse jõudnud tiibeti budismile. Oma olulisimaks õpetajaks peab ta rime õpetussuunda esindanud Jamyang Khyentse Rimpoched. Aastal 1962 sai ta bodhisattva ordinatsiooni geluki koolkonna õpetajalt Dhardo Rimpochelt. Lisaks sai Sangharakshita õpetusi ka dzogtšeni õpetajalt Dilgo Khyentse Rimpochelt, nyingma suunda esindanud Dudjom Rimpochelt ja hiina chani meditatsiooniõpetajalt CM Chenilt. (Liiders 2012b: 60.)

Sangharakshita naasis 1964. aastal Inglismaale ning rajas mõne aasta pärast Londonis uue budistliku organisatsiooni, mis esindas keskteed kahe tol hetkel Inglismaal valitsenud budismimõistmise vahel. Üks neist, English Sangha Trust, pidas ainsaks sobivaks budistliku koguduse vormiks traditsioonilist theravaada mungakogudust, seevastu teine, Buddhist Society näis budismi pidavat pigem spirituaalseks ajaviiteks. Sangharakshitale olid Inglismaal eksisteerivad budistlike organisatsioonide vormid sobimatud ning ta pidas vajalikuks ellu viia omaenda visiooni kaasaegsest budistlikust sanghast ehk kogudusest. (Batchelor 1994: 332-333.) Olles Aasias otseselt kokku puutunud olulisemate budistlike koolkondade õpetustega, võttis Sangharakshita Suurbritannias eesmärgiks rajada läänemaine oikumeeniline budistlik ühendus, mis otseselt ei järgiks ühtki traditsioonilist Ida budismi haru ja oleks suunatud Lääne inimeste spirituaalsetele vajadustele kodumaises kontekstis. 1967. aasta 6. aprillil rajas ta Lääne Budistliku Vennaskonna Sõbrad (Friends of the Western Buddhist Order) ning aasta hiljem Lääne Budistliku Vennaskonna (Western Buddhist Order), mille esimesed liikmed samal aastal ordineeriti.

Vajragupta ehk Richard Staunton, kes 2008. aasta sügisel tegutses õpetajana mitu kuud ka Eestis, märgib oma 2011. aastal avaldatud Triratna ajalugu käsitlevas teoses, et FWBO esialgne edukus Inglismaal oli kindlasti seotud ajastu vaimuga. Mõnel ajaperioodil on ühiskond varasemast radikaalselt erinevate spirituaalsete suundade suhtes avatum, ning 1960. aastad olid Inglismaal sääraseks ajaks, mil just noorem põlvkond soovis end siduda kõigega, mil oli juures revolutsiooniliste muutuste maik. Tol perioodil oli ta üks väheseid budistlikke õpetajaid Läänes (lisaks Shunryu Suzukile ja Chogyam Trüngpale 
USAs), kel õnnestus saavutada kontakt noore kontrakultuuriga ning rajada Läänes edukas budistlik sangha. (Vajragupta 2011: 7-8.)

Kultuurikonteksti ja ajastu vaimuga läks kokku ka see, et liikmed ei pidanud järgima mingeid traditsioonilisi munga- või nunnareegleid. Mis puudutas abielu, tsölibaati ja muid elustiilivalikuid, see jäeti liikmete endi otsustada (Baumann 2006a: 197-198).

1970. aastatel hakati rajama keskusi Mandri-Euroopas ja teistel kontinentidel. Väga oluliseks laienemissuunaks kujunes India lääneosa, kus 1950. aastatel elades oli Sangharakshita toetanud India budistliku poliitiku dr Ambedkari tegevust (Baumann 2006a: 197-198). 1978. aastal rajas Sangharakshita Indias FWBO kohaliku allharu, mis kannab nime Trailokya Bauddha Mahasangha Sahayaka Gana ning ordineeris selle esimesed liikmed. 1980. aastal asutasid WBO liikmed India endiste puutumatute olukorra parandamiseks heategevusorganisatsiooni Karuma Trust. (Vajragupta 2011: 43.) Stephen Batchelor on seda nimetanud Euroopa budistide kõige ulatuslikumaks ühiskondlikuks projektiks läbi aegade, kui silmas pidada abistatud inimeste koguarvu (Batchelor 1994: 365).

1990. aastad olid FWBOl kõige kiirem kasvuaeg: 1994. aastal oli liikmeid veel 600, 2003. aastaks juba 1000. FWBOst oli saanud laiahaardeline ülemaailmne organisatsioon. Seni oli organisatsiooni eesotsas seisnud Sangharakshita üksinda, 21. sajandi alguses hakati tema tervise halvenemise tõttu pidama vajalikuks juhtimisstruktuuri laiendada, et organisatsiooni järjepidevus ei oleks seotud vaid ühe inimesega. Ühtlasi kasvas välismaiste keskuste esindajate hääleõigus organisatsiooni juhtimises. (Vajragupta 2011: 129-131.)

Aastal 2010 muutis organisatsioon oma nime Triratna Budistlikuks Kogukonnaks. Aastaks 2011 oli Triratnal keskusi 36 riigis (Vajragupta 2011: 87). Valdav osa liikmeskonnast elab Suurbritannias ja Indias.

\section{Triratna õpetused kui oikumeeniline budism}

Miks pidada Triratnat oikumeenilise budismi esindajaks? Organisatsiooni rajaja Sangharakshita on rõhutanud, et tema silmis on Triratna budistlik spirituaalne liikumine, mis ei samasta budismi selle idamaiste kultuuriliste avaldumisvormidega ega identifitseeri end ühegi budistliku sekti või koolkonnaga, olgu selleks siis "hinajaana, mahajaana, vadžrajaana, zen, shin või nyingmapad" (Sangharakshita 1990: 17). Triratna ei väida ka seda, et nad esindaksid mingit uut Lääne ümbertõlgendust budismist, pigem väidetakse end esindavat universaalset budismi või universaalset dharmat. (Rawlinson 1998: 503.) Sangharakshita väidab end olevat "algupärase (original) õpetuse vaimu” 
edasiandja ning peab end budistlike õpetuste ümbertõlkijaks Lääne inimeste vajaduste tarvis (Baumann 2006b: 500). Sangharakshita ideaaliks oli ühtne budistlik õpetus, mis ulatuks kaugemale seniste traditsioonide kultuurilistest või ajaloolistest iseärasustest (Lopez 2002: 186-187). Siiski võib tajuda teatud eelistusi, mis tulenevad nähtavasti Sangharakshita õpetajate taustast, kelle hulgas olid ülekaalus theravaada ja tiibeti budistid. Nii võib väita, et Triratna õpetusi on rohkem mõjutanud indo-tiibeti kui hiina ja jaapani budistlikud suunad (Batchelor 1994: 337). Kuigi Sangahrakshita sai oma budistliku mungapühitsuse ja budistliku nime just theravaada traditsiooni raames, ei või teda siiski pidada theravaada budistiks ega näha Triratnat mingi theravaada erivormina, kuna Triratna rituaalidesse ja meditatsioonidesse on koondunud elemendid mitmest India, Tiibeti ja Hiina päritolu traditsioonist; theravaada ortodoksse kloostritraditsiooni ülehindamise suhtes Lääne budistlikes ringkondades on ta aga olnud pigem kriitiline. (Rawlinson 1998: 504.)

Kokkuvõtvalt võiks seega öelda, et Triratna Budistlik Kogukond üritab koondada endas teatud õpetuslikke ja harjutuslikke elemente erinevatest traditsioonilistest budistlikest koolkondadest ja esitada neid Euroopa kultuuriruumis mõistetavas vormis ilma Aasia kultuurilistest või ajaloolistest iseärasustest tuleneva pärandita, esindades seega Lääne budismi oikumeenilist vormi.

\section{Triratna Eesti koguduse ajalugu}

Sangharakshita õpetus levis Eestis kirjasõna kaudu mingil määral nähtavasti juba 1980. aastate esimesel poolel. Dharmachari Sarvamitra meenutab, et ta nägi Eestis olles NSV Liidu ajal tehtud isetegevuslikku väljaannet Sangharakshita raamatust The Three Jewels, mille eestikeelne tõlge oli tehtud 1979. aastal avaldatud soomekeelsest väljaandest Kolme jalokiveä ning kohtus ka tõlke autoriga (Sarvamitra 19.04.2012). Esimesed budismist huvitatud eestlaste sihipärased kontaktid FWBOga leidsid aset 1989. aasta kevadel, mil Anti Kidron ja Aime Hansen Eesti Budistlikust Liidust külastasid Helsingi FWBO keskust ning tundsid huvi, kas soomlased tahaksid Eestisse õpetama tulla. Kutse võtsid vastu Sarvamitra ja tollane Helsingi keskuse esimees Ratnapriya. Esimene WBO liikmete juhendatud meditatsioonilaager Eestis toimus juulis 1989 Põhja-Eestis Andineemes Anti Kidroni talus. Kohaletulnuid oli umbes 30-40. Sarvamitra ja Ratnapriya õpetasid meditatsiooni, tehti austamisrituaale ning samuti tollal FWBO praktikate hulka kuulunud kommunikatsiooniharjutusi. Seda laagrit on peetud Eesti FWBO sünniajaks. 1999. aastal tähistati liikumise kümnendat aastapäeva Eestis just sellest daatumist tulenevalt. Andineeme laagris osalenud Tiia Lõokesest sai peagi põhiline FWBO tegevuse korraldaja 


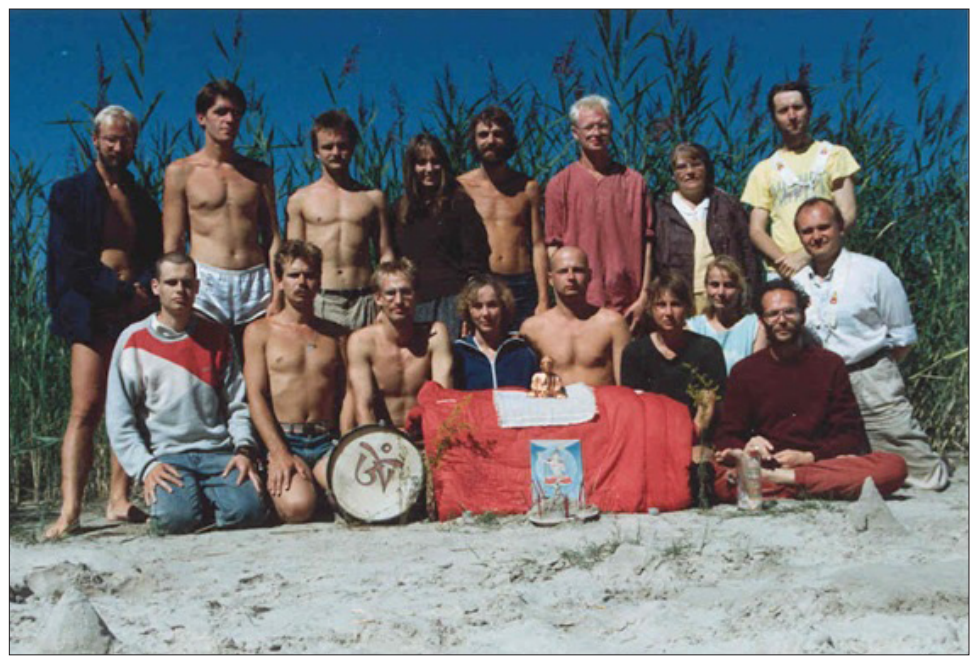

Foto 1. FWBO esimene Eesti laager Andineemes 1989 aasta suvel. Foto erakogust.

ja hoogustaja Tallinnas. Iseseisva budistliku rühmana kohe siiski tegutsema ei hakatud, kuigi 1989. aasta sügisel ja järgnevail aastail käisid Sarvamitra ja Ratnapriya Eestis veel korduvalt õpetamas, tavaliselt mitu korda kuus. Kokkusaamised toimusid nii Budistliku Liidu ruumides Nõmmel kui ka Tiia Lõokese korteris Mustamäel. Eesti religiooniuuringutes on mainitud, et Eestis oli FWBOl juba 1989. aastal umbes 10 aktiivliiget (Ringvee 2000: 111).

Eesti Budistlik Liit, kelle kaudu algne kontakt FWBOga loodi, alustas tegevust aastal 1988 ning koondas Ida õpetustest huvitunud inimesi, kes esialgu ei sidunud end ühegi konkreetse koolkonnaga. EBL registreeris end kultuuriorganisatsioonina ning koondas väga erineva taustaga isikuid: nii Eesti Budistliku Vennaskonnaga seotud rahvast, Ida võitluskunstidest ja hinduismist huvitunuid kui ka A. Kidroni kolleege Mainorist, kelle hulka kuulus ka T. Lõoke (Preem \& Põlenik 2001: 44-45). EBL tegutses üüritud pinnal Nõmmel Põllu tänavas ning lisaks FWBO õpetajatele külastasid ja juhtisid sealseid üritusi ka näiteks Tiibeti budismi esindavad küllasõitnud õpetajad. Kui suur osa EBLi liikmeskonnast liikus viimaks edasi Drikung Kagyu keskuse juurde (Preem \& Põlenik 2001: 48), siis ühtlasi eraldus ja hakkas iseseisvalt tegutsema ka FWBO grupp, mis oli 1990. aastate alguses alustanud eraldiseisvaid, üksnes FWBO õpetustega tegelevaid üritusi Tiia Lõokese korteris Mustamäel.

Tiia Lõoke hakkas pärast Andineeme laagrist saadud positiivset kogemust külastama tihti FWBO keskust Helsingis, osaledes mitraõpingutes ning suveja talvelaagrites. 1991. aasta viimasel päeval sai temast Helsingis esimene eestlasest FWBO mitra. ${ }^{2}$ 
1990. aastatel mängis Soome FWBO keskus Eesti puhul olulist rolli, siinsetel FWBO üritustel osalesid õpetajatena regulaarselt soomlastest WBO liikmed, eelkõige Sarvamitra ja Ratnapriya. Muuhulgas osales Sarvamitra esinejana ka 1992. aastal Peeter Vähi korraldatud idamaise kultuuri festivalil "Orient”. Sarvamitra meenutab, et õpetustegevuse soodustamine ja budismi levitamine Eestis sai Helsingi keskuse liikmetele oluliseks väljundiks. Helsingi keskuses vohasid 1980. aastate lõpus ja 1990. aastate alguses sisekonfliktid. Kuigi vennaskonnaliikmeid oli Soomes tolleks ajaks juba kümmekond, ei õnnestunud neil siiski Soomes Helsingist väljapoole laieneda ning ka tegevus Helsingi keskuses näitas teatud soikumise märke. Sarvamitra hinnangul külastas FWBO üritusi Eestis enamasti rohkem rahvast kui vastavaid üritusi Helsingis. Oma osa selles võis tema hinnangul olla Soome ühiskonnas levinud eelarvamuslikus suhtumises budismi, mis ei tulenenud mitte vastuoludest religioossel pinnal, vaid pigem üldisest reserveeritud hoiakust budismi kui mõistetamatu ja võõra kultuurinähtuse suhtes. Laienemine sai võimalikuks hoopis teisel pool Soome lahte Eestis, kus pärast nõukogude perioodi lõppu oli ühiskond uute religioonide suhtes tunduvalt avatum ja entusiastlikumalt meelestatud. Eesti FWBO kümnenda aastapäeva tähistamisel peetud kõnes mainis Sarvamitra, et soomlaste roll Eestis toimunud õpetustegevuses "päästis ka Soome keskuse" (Sarvamitra 19.04.2012).

Kindlasti kergendas omavahelist suhtlust noil tegevuse algaastatel ka tõsiasi, et soome keele oskajaid leidus Tallinnas piisavalt. Enamasti tõlgiti siiski üritustel kõneldav ka eesti keelde. Inglise keele oskajaid oli FWBO tegevusest huvitatute hulgas tol ajal vähevõitu ning 1991. aastal oli kõne all ka FWBOpoolse keelekursuse korraldamine, mida oleks juhatanud inglasest vennaskonnaliige Virananda. Sarvamitra meenutab, et eesti keel kõlas tol ajal soomlaste kõrvus täiesti arusaamatu võõrkeelena (Sarvamitra 19.04.2012, praeguseks vestleb ta eesti keeles juba vabalt). Aeg-ajalt esines ka kultuurilise konteksti vääritimõistmist, näitena mainib T. Lõoke üht Ratnapriya 1990. aastate alguse loengut maailmarahu teemal, mis kommunismiaja ideoloogilise retoorikaga sarnanemise tõttu tekitas suurel osal kuulajatest ilmselt ebameeldivaid seoseid (Lõoke 30.04.2012).

Oluliseks kujunes eestikeelse tõlkekirjanduse väljaandmine. Aastal 1994 ilmus Sangharakshita Buddha Õilis Kaheksaosaline tee (kirjastus Koolibri) ning 1995. aastal esimene eestikeelne põhjalikum meditatsiooniõpik, Kamalašila Mõtlus, mille andis välja Helsingi FWBO kirjastus. Mõlemat raamatut hakati kohe kasutama ka õpetustegevuses. Raamatud tõlkis Tiia Lõoke, kes ühtlasi tegutses aktiivselt Eestis FWBO tegevuse korraldajana. Aastal 1992 oli Lõoke elanud kuus kuud Inglismaal Londoni kesklinnas FWBO Cherry Orchardi naistekommuunis, töötades Londoni budistliku keskuse right livelihoodi kohvikus. 
Sealviibitud aja vältel osales ta aktiivselt FWBO üritustel ja ka kahe-nädalase vaikusemeditatsiooni laagris Taralokas. Eestisse naastes korraldas ta oma korteris Mustamäel esimese FWBO algajate meditatsioonikursuse, kus osales ka hilisem FWBO mitra Anne Reinjärv. Neid kursusi viidi regulaarselt läbi ka edaspidi. Ühtlasi hakati korraldama mitraõpingute kursusi, kuigi eestlastest mitrapühitsuse saanuid nende tulemusel palju juurde ei tulnud. 1994. ja 1995. aasta suvel korraldati taas Andineemel pikemaid laagreid, mille läbiviijad olid Sarvamitra ja T. Lõoke. Noil aastatel külastasid Eestit ka mitmed inglastest vennaskonnaliikmed. Küllatulnud WBO liikmed esinesid korduvalt ka avalike loengutega, mis peeti suurematel üüritud pindadel (nt Heliloojate Majas, Keele ja Kirjanduse Instituudis, Tallinna Pedagoogilises Instituudis jm).

Aastal 1996 kolis FWBO tegevus T. Lõokese tööruumidesse Kadriorus Poska 10-3, ühtlasi toimusid üritused ka tema töökohas kriisiabikeskuses Aia tänavas. ${ }^{3}$ Endiselt korraldati ka meditatsioonilaagreid, muuhulgas ka eraldi meestele ja naistele mõeldud laagreid. Tähistati budistlikke tähtpäevi, näiteks Buddha virgumise päeva (parinirvaana) ja sünnipäeva (vesak), samuti koguduse ehk sangha päeva. Aastal 1996 hakkas FWBO tegevuses osalema Taivo Org, kes 1998. aasta sügisel pühitseti kolmanda eestlasena mitraks (Org 15.03.2012). 1997. aastal külastas Eesti FWBOd Jukka Nuutilainen (WBO vennaskonnaliige Manjudaaka), kellest kujunes hiljem siinse FWBO tegevuse peamine rahaline toetaja. 1997. aasta lõpul valmis Eesti FWBO internetilehekülg, mida mitmed tegevuses osalejad on nimetanud peamise allikana, kustkaudu organisatsiooni tegevusest Eestis esmakordselt teada saadi. 1997. aasta sügisest alates peeti iga kahe-kolme nädala tagant laupäeviti ka regulaarseid üritusi, mis koosnesid meditatsioonist, pujarituaalist ja teejoomisest. ${ }^{4}$

2000. aasta aprillist kolis FWBO oma tegevuse üle Taivo Oru korterisse Tartu mnt 67-24, mille üürimist toetasid rahaliselt soomlastest vennaskonnaliikmed. Peeti suviseid laagreid Võerahansu talus Raplamaal, samuti Soomaal ja Randveres Viimsi vallas.

Oluliseks momendiks Eesti FWBO liikumise arengus oli kolimine oma pinnale Tallinna vanalinna aadressil Sulevimägi 5. Hoone ostis Soome vennaskonnaliige Manjudaaka 8. märtsil 2001 osalt isikliku investeeringuna, osalt soovist kindlustada FWBO Eestis püsivama peavarjuga . Sulevimäe maja teisele korrusele seati sisse altariruum, kuhu mahtus mediteerima mitukümmend inimest. Maja avati pidulikult 17. veebruaril 2002, kohale saabus umbes 50 inimest, sealhulgas kutsutud külalised Soomest, Inglismaalt, Venemaalt ja Rootsist. Planeeriti ka FWBO rajaja Sangharakshita külaskäiku Eestisse 2002. või 2003. aastal, kuid tema tervisliku seisundi halvenemise tõttu ei osutunud see võimalikuks (Lõoke 1.05.2012). 
2003. aastaks oli Eestis mitra-tseremoonia läbi teinud kuus inimest. Senini ei olnud veel ühtki kohalikku WBO vennaskonnaliiget, samuti puudus kohapeal resideeruv õpetaja, endiselt toimus suur osa õpetustegevusest tänu külaskäivatele WBO liikmetele Soomest ja Inglismaalt. WBOga liitumist taotles Tiia Lõoke, kes oli 1999. aasta suvel Soomes läbi teinud kalyanamitra tseremoonia ning osales liikmeks saamise eesmärgil korduvalt Walesis Triratnaloka keskuses mitmenädalastes laagrites (pikemat mitmekuist laagrit, mis liikmeks ordineerimisele tavaliselt eelneb, takistas rahanappus). Tiia Lõoke pühitseti Lääne Budistliku Vennaskonna liikmeks 2003. aasta augustis Triratnaloka keskuses (Lõoke 1.05.2012). Tema budistlikuks nimeks sai Dharmacharini Amaradakini. Tiia Lõoke on maininud, et peagi pärast liikmekspühitsemist hakkas tema huvi budismi vastu mõneti vähenema ning ta hakkas rohkem huvituma new age'i praktikatest, eelkõige vabastavast hingamisest, mille õpetajana ta ka praegu tegutseb (Lõoke 30.04.2012). Oma osa ainsa eestlasest WBO liikme kohalikust õppetegevusest kaugenemisel võis olla ka selles, et Budakoja juhtimises leidsid aset muutused. Seni olid kohalikku FWBO tegevust korraldanud eelkõige T. Lõoke ning eestlastest mitrad T. Org ja A. Reinjärv koostöös Sarvamitra ja Manjudaakaga, nüüd leiti ühiselt, et seoses püsivasse asukohta kolimisega ja sellest tulenevate avardunud võimalustega õppe- ja harjutustegevuseks on tekkinud vajadus täiskohaga õpetaja järele. 2004. aasta sügisel saabus Manjudaaka stipendiumi toetusel Eestisse püsivalt elama ja õpetama inglasest vennaskonnaliige Birminghami FWBO keskusest - Dharmachari Vaddhaka (Ian Linn).

Vaddhaka tulekuga hoogustus tegevus Sulevimäe Budakojas (nagu seda nüüd nimetati). Lisaks esmaspäevaõhtustele meditatsioonist ja pujarituaalist koosnevatele üritustele hakati meditatsiooniüritusi korraldama ka laupäeviti. Üritati juurutada ka varahommikuste meditatsioonide tava, mis on levinud näiteks Inglismaa FWBO keskustes, võimaldades töölkäijatel enne päevakohustuste algust keskuses harjutada. Kumbki uuendus siiski püsima ei jäänud, sest osalejaid polnud piisavalt. Endiselt korraldati algajate meditatsioonikursusi ja õpperühmi ning loenguõhtuid budistlikel teemadel. Pühitseti ka kaks uut eestlasest mitrat. Vaddhaka hakkas aktiivselt kontakte otsima teiste budistlike rühmade ja institutsioonide ning ka budismist huvitatud kultuuritegelastega (näiteks Jaan Kaplinski). Vesaki päeva tähistamisele 13. mail 2006 kogunes Sulevimäele budiste mitmetest teistestki Eesti budistlikest kogudustest, esinesid Märt Läänemets Budismi Instituudist ja Andres Zelmin Eesti Dzogtšeni rühmast, ürituse lõpupalved viisid läbi Drikungi keskuse esindajad. Vesaki tähistamine budakojas erinevaid Eesti budistlikke kogudusi ühendava pidupäevana on 2006. aastast alates kujunenud oluliseks traditsiooniks. 
2005. aastal korraldati suvine meditatsioonilaager Vaddhaka juhtimisel Tartu lähedal Trangis. Alates 2006. aastast on Eesti FWBO suvised laagrid toimunud Taivo Orgi talus Põlvamaal Kamnitsas. Lisaks korraldati ka muudel aastaaegadel nädalalõpulaagreid, mis tihti leidsid aset Kamnitsas, aastatel 2006-2007 ka Villa Onni puhke- ja õppekeskuses Jõelähtme lähedal. Lisaks toimusid Sulevimäe Budakojas meditatsioonipäevad (peamiselt pühapäeviti).

2008. aasta mais siirdus Eesti FWBO uude asukohta Luha ja Koidu tänava nurgal Uue Maailma linnaosas. Ka Luha 1 aadressil asuv maja oli Manjudaaka hangitud, ent seekord anti maja kaks ülemist korrust juba pikemaaegse rendilepinguga (pigem sümboolse tasu eest) püsivamalt Budakoja hallata. Maja kolmandal korrusel asub altariruum, kuhu mahub üle kolmekümne mediteerija.

Ka pärast Luha tänavale kolimist on Budakoja tegevuse aluseks iganädalased meditatsiooniõhtud. Esimese osa moodustab meditatsioon kestusega umbes 40 minutit. Meditatsioonile eelneb lühike altaritervitus. Üldjuhul on meditatsiooniks üks kahest FWBO baasharjutusest: kas hingamise teadvustamine või mettā bhāvanā. Kui harjutajate hulgas on uustulnukaid ja algajaid, antakse iga meditatsiooniastme alguses suusõnalisi juhiseid. Kui aga kõik harjutajad on meditatsioonitehnikaga tuttavad, toimub meditatsioon vaikuses ja kellahelinaga antakse märku vaid iga etapi algusest. Meditatsioonile järgneb lühike paus. Seejärel leiab aset rituaal (seitsmekordne puja), mis koosneb seitsmeosalise pühendusteksti (kohandatud Linnart Mälli Bodhitšarjāvatāra ja Südasuutra tõlgetest) ühisest ettekandmisest ja mantrate retsiteerimisest koos annetustega altarile. Puja asemel leiab vahel aset teine meditatsioonisessioon või loeng. Osalejaid on Tallinna esmaspäevastel meditatsiooniõhtutel keskmiselt 10-15. Suvel meditatsiooniõhtuid tavaliselt ei korraldata.

Teisipäeva õhtutel on regulaarselt aset leidnud algajate meditatsioonikursused, kus õpetatakse hingamise teadvustamist ja mettā bhāvanāt, tutvustatakse ka budistlikke aluspõhimõtteid (kaheksaosaline tee). Viimaste aastate jooksul on korraldatud ka süvendatud meditatsioonikursusi edasijõudnutele vipassana $\bar{a}$, brahmavihaarade ja kuue elemendi meditatsioonide teemal.

Pühapäeva pärastlõunatel (vahel ka kolmapäeviti) tutvustatakse loengukursustel budistliku tee erinevaid aspekte. Teemadeks on olnud bodhisattva ideaal, kaheksaosaline tee, mitra alusõpingud. Teisipäeviti ja kolmapäeviti on korraldatud filmiõhtuid. Endiselt peetakse ka meditatsioonipäevi ning tähistatakse budistlikke aastapäevi (vesak, parinirvaana ja sangha päev). Sangha päeval on aastatel 2010-2012 pühitsetud viis uut mitrat.

Tartus alustati regulaarsete FWBO meditatsiooniõhtutega 2008. aasta alguses. Peamiseks Tartu tegevuse vedajaks sai Tallinnast Tartusse kolinud Taivo Org. Kuna Tartus Triratna organisatsioonil püsivat rendipinda pole, on neljapäevaõhtuste meditatsiooniürituste asukoht korduvalt muutunud. Oma 
pinna puudumise tõttu pole olnud võimalik sisse seada altariruumi, seetõttu ei esine Tartu üritustel ka altaritervitust, mantraid ja pujarituaale.

\section{Osalejaskonna liigitus}

Triratna tegevuses osalejad jagunevad kolmeks: külastajad, mitrad ja vennaskonnaliikmed. Tallinna Budakoja ja Triratna Tartu ürituste peamised osalejad pole ametlikult Triratna Budistliku Kogukonnaga seotud, neid võib nimetada tava- või juhukülastajateks. Külastajate olulisus organisatsiooni identiteedis kajastus ka selle varasemas nimes Lääne Budistliku Vennaskonna Sõbrad (Friends of Western Buddist Order), kus sõna “sõbrad” viitas just külastajatele, kel pole ametlikku liikmestaatust. Eeldasin esmalt, et sõna viitab pühitsuse saanutele ehk mitratele (skr sõber), kuid vennaskonnaliikmete Saddhaloka (13.04.2012) ja Vaddhaka kinnitusel peetakse sõprade all silmas tavakülastajaid. Mitmed tavakülastajad on Budakoja üritustel osalenud rohkem või vähem regulaarselt juba aastaid, mitmed neist peaaegu iga nädal, kuid pole end veel Triratna organisatsiooniga mitrapühitsuse teel sidunud. Vaddhaka mainib, et Inglismaal on regulaarkülastajad mitrapühitsuse vastuvõtmiseks altimad ning tihti toimub see pärast aastast Triratna tegevuses osalemist (pühitsusele eelnevaks miinimumperioodiks, mil inimene peaks olema Triratna tegevuses osalenud, on kuus kuud). Ta leiab ka, et paljusid regulaarkülastajaid Eestis võiks pühendumise ja organisatsiooni tegevusse haaratuse poolest pidada võrdväärseks teiste riikide keskuste mitratega, kuid Eestis ollakse pühitsuse võtmise suhtes kaalutlevamad (Vaddhaka 7.03.2012).

Enamikul Eesti Triratna tegevuses osalejatest ei ole budistlikku pühitsust ja nad ei pruugi end budistidena määratleda, kuigi mitmed regulaarkülastajad on varasematel aastatel olnud tihedalt seotud ka koguduse tegevuse korraldamisega ning osalenud selle formaalsetes ja mitteformaalsetes juhtimisinstitutsioonides. Viimasel ajal on see tendents vähenemas ning liikmetena võib 2012. aasta seisuga käsitleda mitrapühitsuse saanuid, kes aktiivselt koguduse tegevuses osalevad. Mitrapühitsuse saanud määratlevad end pühendunud praktiseerivate budistidena ning on andnud viiest käitumisjuhisest kinnipidamise lubaduse, mis kohustab neid elama budistlikest eetilistest tõekspidamistest lähtuvalt.

Kahekümne nelja tegevusaasta jooksul on mitrapühitsuse saanud 13 eestlasest Triratna budisti. Neist umbes pooled on praegu Triratna tegevusega iganädalaselt seotud ja neid võib määratleda koguduse aktiivliikmetena. Sõna mitra tähendab sanskriti keeles sõpra. Mitra (vahel kasutatakse ka vormi dharma-mitra ehk seadmusesõber) on inimene, kes on pikemat aega Triratna tegevuses osalenud, peab budistlikku õpetust oluliseks ja otsustab võtta mit- 
rapühitsuse. Mitraks saamisega kinnitab see inimene järgmist: 1) ta peab end budistiks; 2) ta üritab järgida viit käitumisjuhist; 3) Triratna on peamiseks kohaks, millega ta vähemalt lähiajal oma vaimse tee seostada tahab. ${ }^{5}$

Mitra pühitsusrituaalina viiakse läbi seitsmekordne puja, kus pärast teksti esimese osa ettekandmist lähevad mitraks saada soovijad altari ette, annetavad küünla ja viiruki ning annavad lubaduse järgida viit käitumisjuhist. Pärast tseremooniat õnnitlevad värskeid mitrasid teised Triratna mitrad, vennaskonnaliikmed ja kohalviibivad tavakülastajad ning annavad üle kingitusi ja õnnitluskaarte (osalusvaatlus 22.11.2011).

Intervjueerides Eesti Triratna tegevuses viimase paari aasta vältel aktiivselt osalenud viit mitrat, tundsin huvi, miks nad otsustasid saada mitraks. Neljast vastajast viis nägid selles eelkõige budistlikule harjutusteele pühendumise kinnitust. Neile oli oluline just avaliku kinnituse moment kui psühholoogiline mõjutegur, mis paneb pühendunumalt praktiseerima. Kui need neli vastajat nägid mitraks saamises eelkõige olulist sammu isikliku vaimse arengu kontekstis ega maininud liikumise huve, siis viienda vastaja puhul oli rõhuasetus mõnevõrra teine. Tema nägi seda eelkõige otsusena, mis teenis liikumise pikemajalisi huve. Ta leidis, et mitraks saamine kinnitab, et temagi kavatseb anda õpetustegevusse oma panuse, mainides ka, et kõik on surelikud ning keegi peab kunagi hakkama õpetust edasi kandma.

Ükski küsitletutest ei leidnud, et mitraks saamine oleks tema budistlikus elus kaasa toonud märkimisväärseid muutusi. Mainiti, et see on aidanud tunda end suuremal määral Triratna rahvusvahelise kogukonna liikmena, pannud pühendunumalt praktiseerima ja eetilisemalt käituma. Kõik mitrad olid enne pühitsusrituaali osalenud Triratna tegevuses vähemalt kaks aastat, mõni ka oluliselt kauem.

Mitraks saamine eeldab avalikku pühitsusrituaali sooritamist, seevastu mitrastaatusest loobumiseks mingit avalikku kombetalitust ette nähtud pole. Dharmachari Vaddhaka sõnutsi tuleb otsest mitrastaatusest loobumist ette harva, pigem jäädakse formaalselt Triratna mitraks ka siis, kui Triratna tegevusest ja liikmeskonnast mitmesugustel põhjustel kaugenetakse (Vaddhaka 4.04.2012).

Triratna Ordineeritud Budistide Ühenduse (Triratna Buddhist Order, aastani 2010 Western Buddist Order ehk Lääne Budistlik Vennaskond) liikmed on praktiseerivad budistid, kes on andnud end organisatsiooni ordinatsioonireeglite kohaselt kolme kaitse alla (Buddha, dharma ehk seadmus/õpetus ja sangha ehk kogudus), võtnud endale budistliku nime ning on tihedalt seotud teiste vennaskonnaliikmetega, kelle seast on nad valinud enda vaimset arenguteed toetama isiklikud ja avalikud õpetajad. Vennaskonna liikmeks saamine kehastab traditsioonilise munga- ja nunnapühitsuse läänemaistele oludele 
kohandatud varianti, kus on säilinud pühendumine õppimisele ja harjutustele ning eetiliste põhimõtete järgimisele, kuid puuduvad elustiilivalikuid määravad reeglid. Vennaskonnaliikmeid on eestlaste seast tulnud kaks, kellest üks enam Triratna tegevuses aktiivset rolli ei mängi.

Jaanuaris 2013 viidi Tallinnas Budakojas läbi Taivo Oru avalik liikmekssaamise tseremoonia, tema budistlikuks nimeks sai Dharmachari Bodhikara. Enne oli T. Org läbinud liikmessaamise laagri Soomes, kus toimus tema isiklik pühitsustseremoonia. Enne liikmekssaamist tuleb lisaks läbida vähemalt kuus süvendatud õppelaagrit (see võib toimuda küllaltki pika ajavahemiku jooksul). T. Oru puhul toimusid kõik laagrid välismaal, enamasti Suurbritannias.

Privaatse liikmekspühitsemise täpsed detailid on konfidentsiaalsed, neist ei räägita avalikult, osaliselt ka tagamõttega, et seda pöördelist hetke pühitsetava elus ümbritseks müstilisuse oreool ja see omandaks uude eluetappi sisenemise tähtsuse. Triratna Avalike Juhendajate Kolleegiumi liige Dharmachari Saddhaloka mainib siiski, et selle vestluse käigus võidakse anda näiteks soovitus keskenduda mingile praktikale, mis isikliku õpetaja arvates liikmekssaajale sobib, kuigi selle otsuseni jõutakse mõlemapoolsel nõusolekul (Saddhaloka 15.03.2012).

Taivo Oru avalikul liikmekspühitsemisel 6. jaanuaril 2013 osalesid paljud Triratna ordineeritud liikmed Soomest, samuti valdav osa Eesti Triratna tegevusega seotud inimestest. Avalik õpetaja Dharmachari Padmavajra Inglismaalt selgitas esmalt liikmekssaamise tähendust, misjärel algas tseremoniaalne osa:

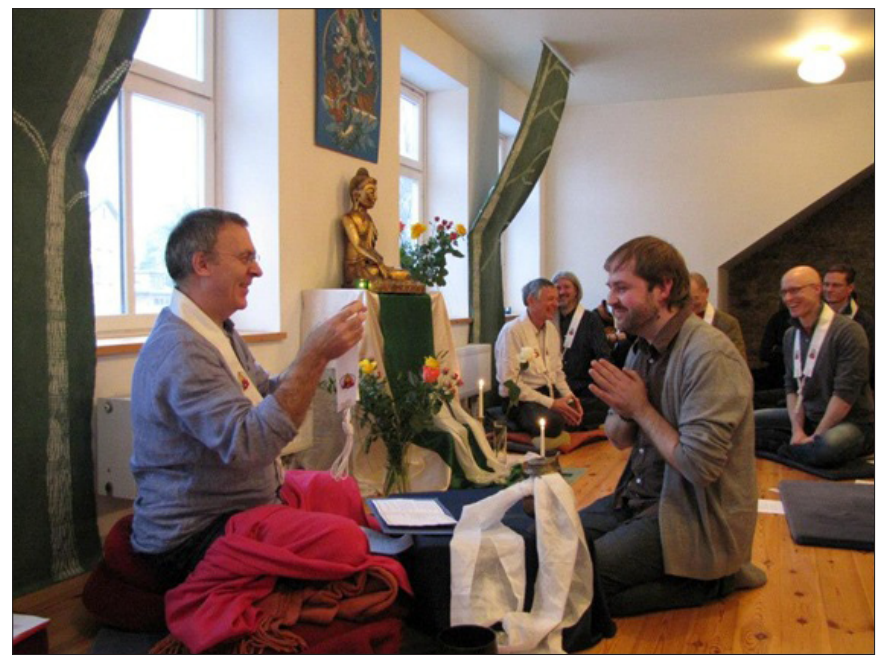

Foto 2. FWBO Dharmachari Bodhikara Triratna Ordineeritud Budistide Ühenduse liikmekssaamise avalik tseremoonia Budakojas 6.01.2013. Foto Budakoja arhiivist. 
liikmekssaaja annetas Buddha kujule lille, küünla ja viirukipulga, millele järgnes seitsmekordse puja ühine ettelugemine inglise ja eesti keeles. Avalik õpetaja luges siis ette viis paalikeelset käitumisjuhist, mida liikmekssaaja kordas, kinnitades seejärel kolme kaitse all mineku läbi soovi saada Triratna liikmeks. Avalik õpetaja võttis soovi vastu ja valas liikmekssaanu pähe pühitsetud vett. Seejärel avaldas isiklik õpetaja Dharmachari Saddhaloka uue liikme budistliku nime (mida ta usulises kontekstis, kuid soovi korral ka tavaelus edaspidi kasutab) ja selgitas selle tähendust. Kõik kohalviibijad õnnitlesid uut liiget tseremoniaalsel kombel, hüüdes kolm korda "Sādhu!" ja visates tema suunas konfette (osalusvaatlus 6.01.2013 Tallinna Budakojas).

\section{Eesti Triratna liikmeskonna üldiseloomustus}

Mitrate ja vennaskonnaliikmete suhteliselt väike pühitsuste arv Eesti Triratna koguduse puhul võib olla tingitud eestlastest budistide rahanappusest, mis piirab osalemist välismaal meditatsioonilaagrites, mis on üldjuhul pühitsuse saamise eelduseks. Eesti koguduse aktiivliikmed on tavalised eestlased, kes määratlevad end praktiseerivate budistidena, on läbi teinud mitrapühitsuse ja külastavad üritusi kõige rohkem mõned korrad nädalas. Nad usuvad mingil määral budismis olulistesse doktriinidesse, nagu karma ja ümbersünni õpetus, kuigi tõlgendavad neid isiklikest seisukohtadest lähtuvalt, mitte traditsioonilise budismi vaatekohast. Eestis pole kunagi tegutsetud budistliku kommuunina, kus liikmed püsivalt elaksid.

Antud uurimuse raames küsitleti nende isiklike ja budistlike vaadete, praktika ja liikmelisusajaloo asjus põhjalikumalt kõiki Eesti Triratna tegevuses aktiivselt osalevaid mitraid, samuti viit regulaarkülastajat, kes kõik on vähemalt kaks aastat Eesti Triratna kogudusega aktiivselt seotud olnud. Viiest regulaarkülastajast kolm määratlesid ennast budistina. Kõik vastajad on viimase aasta jooksul regulaarselt osalenud Eesti Triratna tegevuses, enamik külastab (või juhib) Triratna üritusi keskmiselt korra nädalas. Vastanutest kolm on hetkel seotud eelkõige Tartu rühmaga, kuigi on tihti külastanud ka Tallinna üritusi. Võrdlesin kahe rühma (mitrate ja regulaarkülastajate) vastuseid, et teha kindlaks, kuivõrd erinevad formaalse liikmepühitsusega budistide vaated, uskumused ja elustiilivalikud budismist aktiivselt huvitatute omast.

Valdav osa küsitletutest ei määratlenud budismi enda silmis usuna, vaid pigem spirituaalse ja/või filosoofilise maailmavaatena või harjutusteena. Nõnda tuleb välja, et kuigi Eesti Triratna tegevuses osalejad tegelevad üritustel regulaarselt budistlike praktikatega, mida iseenesest võiks hinnata religioosse sisuga toiminguks, ei määratle enamik end usklikuna. Viis küsitletut oli varem 
osalenud mõne kristliku kiriku tegevuses (enamjaolt luteri kiriku), nad kõik olid üle 40 aasta vanad ning enamikul jäi kristlik periood 1990. aastate esimesse poolde, praegu enam ükski neist end kristlaseks ei pea. Vastanutest pooled olid osalenud ka muude budistlike organisatsioonide tegevuses (peamiselt mainiti küll vaid Budismi Instituudi loenguid), seega on Triratna osalejate enamusele ainus liikumine, kus nad budistliku praktikaga tegelevad. Kõik küsitletud on osalenud Triratna meditatsioonilaagrites Eestis, enamik neist korduvalt. Kõik mitrad on osalenud Triratna laagrites ka välismaal, regulaarkülastajate hulgast oli välismaa laagrites käinud kolm vastajat. Valdav osa küsitletutest polnud enne Triratnasse tulekut budistliku praktikaga tegelenud, kuigi kõigil oli teatud kokkupuuteid budistlike õpetustega, mis üldjuhul olid saadud raamatutest. Liikmete (mitrate) pühendumine kogudusele avaldub eelkõige liikumise töö edendamises, kus aega ja energiat pühendatakse näiteks õpetustegevuse toetamisele ja keskuse igapäevaasjade korraldamisele. Rahaliste annetustega liikmed Eesti Triratna tegevust ei toeta, makstes samu osalustasusid, mis tava- ja juhukülastajad. Religioosses plaanis on pühendumine jäetud suuresti iga inimese enese hooleks ning see sõltub isiklikest tõekspidamistest.

Küsimusele, mis motiveerib inimesi Triratna tegevuses osalema, vastati üsna sarnaselt. Peamise põhjusena toodi välja teiste harjutajate toetus ja jagatud kogemus, sarnaste väärtushinnangute ja eesmärkidega inimeste positiivne mõju. Et enamik küsitletutest polnud teistes budistlikes liikumistes osalenud, ei ole üllatav, et võrdlus teistega puudus vastustes täielikult; keegi ei väitnud end osalevat Triratna tegevuses seetõttu, et peab seda parimaks kättesaadavaks budistlikuks õpetuseks või koguduseks. Enamik vastanutest pidas oluliseks ka sõpruse rolli budistlikus koguduseelus. Omavahelist sotsiaalset läbikäimist väljaspool Triratna üritusi just tihedaks ei peetud, kuid leiti, et seda võiks rohkem olla. Mõni vastaja pidas suhtluse kohatise vähesuse põhjuseks eestlastele omast tagasihoidlikkust, mida Vaddhaka iseloomustas sõnadega: "I don't think Estonians do sangha naturally" (umbkaudne mõte: minu arvates pole eestlastele koguduse moodustamine loomuomane) (Vaddhaka 4.04.2012). Takistava tegurina mainiti ka ajapuudust.

Eesti budistide ühiskonnaga seotust on varem uurinud Ave Põlenik, kes peab eesti budistlikke kogudusi muu ühiskonnaga kohanenud vähemuseks, kuigi leiab, et budistlik kogukond tervikuna jääb ühiskonnaga suhteliselt vähe seotuks (Põlenik 2004: 92). Eesti Triratna puhul võib kohalikku kogukonda assimileerumise katseks pidada näiteks Uue Maailma tänavafestivalidel osalemist pärast Luha tänavale kolimist, kusjuures festivali kestel on Budakoja ruumid huvilistele avatud, ning üritatakse tutvustada meditatsioonimeetodeid ja keskuse tegevust. Liikmeskonna küsitlemisel ei ilmnenud, et budistid oleksid langenud Eesti ühiskonnas usuliste eelarvamuste või tõrjutuse ohvriks. Pea- 
miste oma tutvusringkonnas kogetud reaktsioonidena budismi suhtes mainiti neutraalsust, huvipuudust või huvitatust, küll aga lisati, et mõnel juhul suhtutakse eelarvamuslikult budistliku maailmavaatega kaasnevatesse elustiilivalikutesse, nagu taimetoitlus või alkoholi mittetarvitamine.

Küsitluste põhjal selgus, et Eesti Triratna mitratest aktiivliikmed määratlevad end budistidena, usuvad enamasti karma õpetusse ning pööravad võrdlemisi suurt tähelepanu budistlikele eetikapõhimõtetele, üritades mõtestada budistlikke käitumisjuhiseid tavaelu seisukohast. Nende suhtumist budistlikku ümbersünniõpetusse saab kõige paremini edasi anda mõistega agnostiline. Regulaarkülastajate suhtumine karma ja ümbersünni õpetusse on sarnane, kuigi nad ei määratle end tingimata budistidena ega pruugi olla andnud lubadust pidada kinni viiest käitumisjuhisest. Täheldatav on püüd muuta toitumisharjumusi, et vähendada lihasöömist (kuigi see üldjuhul ei väljendu täistaimetoitluses).

\section{Praktika budismis}

Triratna budismis ning ka Lääne budismis üldisemalt esineb sageli termin praktika või harjutamine. Mida see budistlikus kontekstis tähendab?

Carl Bielefeldt eristab budismi puhul nelja ingliskeelse sõna practice kasutusviisi. Esiteks märgib see aktiivset harjutamist ja regulaarset budistlikest üritustest osavõttu praktiseeriva budistina. Teises tähenduses on praktika teooria vastand, nagu näiteks budistlikest pühakirjadest loetud õpetuste ellurakendamine. Kolmas tähendus: praktika kui milleski kogenud olemine korduva harjutamise tagajärjel, mida eesti keeles võiks kokku võtta väljendiga "harjutamine teeb meistriks", kuid budistlikus kontekstis võidakse kellegi kohta öelda ka: “Ta on harjutamises kaugele jõudnud.” Neljandas tähenduses avaldub praktika seotus põhimõtetega, s.t harjutuspõhimõtete järgimine või mittejärgimine igapäevaelus (näiteks kas traditsioonilise vaesusvande andnud mungad seda ka praktikas järgivad). Bielefeldt rõhutab, et mõiste praktika kasutusviisid võivad budistlikus elus seetõttu olla oluliseks märguandjaks selle kohta, kas harjutaja järgib õpetusteed või on kõrvaltvaatajate arvates sellest kõrvale kaldunud (Bielefeldt 2005: 229-230). Üldiselt avalduvad kõik Bielefeldti mainitud praktika tõlgendusvõimalused ka Triratna tegevuses.

Valdav osa Eesti Triratna tegevuses osalejatest on praktiseerivad budistid. Kuigi Triratna tegevuses on varasematel aastatel ürituste kirjelduses tihti kasutatud ka terminit "meditatsioonipraktika", ${ }^{6}$ eelistatakse tänapäeval Eesti Triratna koguduses rääkida pigem harjutamisest, mitte praktiseerimisest. ${ }^{7}$ Kõik Eestis mitrapühitsuse saanud on tegelenud regulaarselt meditatsiooniga 
Eesti Triratna ürituste raames, olles seega praktiseerivad budistid. Praktika oma teises tähenduses (õpetuste mõistmine praktika kaudu) avaldub Triratna kirjeldustes teadvuse kõrgematest seisunditest ehk dhyānadest, mille kohta õpetustes mainitakse, et kuigi neid võib kirjeldada, on neid seisundeid võimalik tõeliselt mõista üksnes pühendunult harjutades ja seeläbi neid loodetavasti kunagi kogedes (Kamalašila 1995: 71-83). Kogemuse aspekti tähtsustamine kolmandas tähenduses avaldub näiteks selle kaudu, et ka mitrapühitsust mitteomav O. Kangur on Triratna üritustel meditatsioone juhendanud (osalusvaatlused Tallinna Budakojas 16.04.2012 ja 23.04.2012), kuna ta on budistliku meditatsioonipraktikaga tegelenud aastaid. Bielefeldti poolt neljandana mainitud praktika seosed põhimõtetega avalduvad aga näiteks sel moel, et mitrapühitsuse jooksul antud viiest käitumisjuhisest kinnipidamise lubadused on Eesti Triratna puhul sõnastatud just harjutuspõhimõtetena, mille rakendusvõimalusi arutatakse mitraõpingutes.

Peamiseks praktikaks või harjutusviisiks on Triratna Budistlikus Kogukonnas meditatsiooniharjutused, mille hulgas kõige olulisemaks on hingamise teadvustamine ja mettā bhāvanā ehk armastava sõbralikkuse arendamine (lisaks võib nimetada veel lihtsalt istumise, brahmavihaarade, kõndmeditatsiooni, kuue elemendi, Buddha omaduste meeldetoomise jm praktikaid). Lääne budismiuurijad on kahte peamist Triratna meditatsiooni nimetanud algupäraselt theravaada traditsioonist pärinevaks (Morrison 2006: 194; Baumann 2006a: 197). Regulaarse meditatsioonipraktikaga tegelevad kõik koguduste üritustel aktiivselt osalevad mitrad, samuti enamik tavakülastajatest.

\section{Eesti Triratna tegevuses osalejate suhtumisest praktikasse}

Üldiselt peavad regulaarset meditatsioonipraktikat oluliseks nii mitrad kui ka tavakülastajad, kuigi enamasti ei seata selle olulisust kõrgemale kõlbelisest käitumisest. Enamik mitratest tegeleb ka kodus igapäevase meditatsioonipraktikaga, tavakülastajad pigem mitte, kuigi esines ka erandeid. Kõik küsitletud olid regulaarselt tegelenud nii hingamise teadvustamise kui ka metta bhāvanāga, kõik mitrad ja enamik tavakülastajatest oli puutunud kokku lihtsalt istumise, kõndmeditatsiooni ja brahmavihaarade tehnikatega. Ülejäänud vähemlevinud meetoditega olid tuttavad mitrad, tavakülastajate puhul sõltus kursisolek pikemates meditatsioonilaagrites osalemisest. Suur osa vastajatest jõudis Triratna tegevuses osalemiseni just huvist meditatsiooni vastu, kusjuures mitmel juhul ei määratletud end eelnevalt budistina ega oldud budismi õpetustest sügavamalt huvitatud. 
Palusin Triratna harjutajatel iseloomustada oma kogemusi ja eelistusi seoses kolme enimkasutatava Triratna praktikaga (hingamise teadvustamine, mett $\bar{a}$ bhāvanā ja lihtsalt istumine).

Hingamise teadvustamise puhul mainiti esilekerkivat tähelepanelikkust oma tajukogemuste suhtes, mida tavaliselt ei täheldata. Kaks mitrat mainis lühiajaliste dhyāna-kogemuste teket. Mettā bhāvanā puhul oli oluliseks eelkõige eetiline perspektiiv: aitab arendada empaatiat teiste inimeste suhtes ja neid paremini mõista, muudab avatumaks ja heasüdamlikumaks ja seda saab rakendada inimsuhete parandamiseks. Lihtsalt istumisega oli vastajatel kõige keerulisem suhestuda, kuna konkreetne eesmärk puudub. Mainiti küll, et tihti on tegu lõõgastava ja vabastava praktikaga, kus "harjutuse lähtekohaks on meel sellisena, nagu see praegu on".

\section{Kokkuvõte}

Triratna kogudus Eestis on rahvusvahelise oikumeenilise budistliku organisatsiooni alamharu ning selle püsimajäämist ja arengut on oluliselt mõjutanud välismaised õpetajad ja toetajad. Eesti sangha on olemuselt pigem mitteformaalne ja pühitsust ei tähtsustata, mida kinnitab üsna väike mitrate ja vennaskonnaliikmete pühitsuste arv 24 tegevusaasta jooksul. Üle poole aktiivsetest tegevuses osalejatest pole Triratna mitrad ega vennaskonnaliikmed ning peavad end budistiks isiklike väärtushinnangute põhjal. Kohalikku sanghat ühendab eelkõige meditatsioonipraktika, kommuunielu puudub ning väljaspool Triratna üritusi üksteistega tihedalt ei suhelda. Organisatsioonil puudub liikmemaks ning aktiivliikmete vaateid, praktikat ja eraelu ei kontrollita ega mõjutata aktiivselt. Õpetusi ja meditatsioonipraktikaid võib kirjeldada oikumeenilise Lääne budismina, mis pole otseselt seotud ühegi traditsioonilise idamaise õpetusliiniga. Praktikat ehk harjutamist peetakse koguduses oluliseks ning selle põhiliseks väljenduseks on meditatsioonitehnikatega tegelemine iganädalastel regulaarüritustel ja pikemates harjutuslaagrites ning eraviisiliselt. End budistina määratlevad Triratna liikmed peavad oluliseks mediteerimist ja kõlbelisi eluviise, mis võivad mõjutada ka nende elustiilivalikuid, kuid budismi üldjuhul usuna ei tõlgendata ja ennast usklikuks ei peeta.

\section{Kommentaarid}

1 Artikli valmimist toetas Euroopa Liit Euroopa Regionaalarengu Fondi kaudu (Kultuuriteooria Tippkeskus).

${ }^{2}$ Mitra (skr sõber) - FWBO tseremoniaalse pühitsuse saanud budist, kes annab viiest käitumisjuhisest kinnipidamise lubaduse. 
3 Tiia Lõokese koostatud FWBO ürituste loetelu.

4 Tiia Lõokese koostatud FWBO ürituste loetelu.

5 Budakoja budistliku eetika mitrakursuse õppematerjalid (http://www.budakoda.ee/ tl_files/mitrakursus/eetika/budistliku_eetika_kursus.pdf - 15.03.2013).

${ }^{6}$ Elektroonilised teated 24.08. 2005, 23.08.2006, 11.08.2006 Budakoja meililistis.

7 Eesti budistlikes ringkondades kasutatakse praktika tähistamiseks lisaks meditatsioonile veel näiteks nimetusi mõtlus või meeleharjutus, ent kuna Triratna eelistab terminit meditatsioon, kasutan käesolevas artiklis seda.

\section{Allikad}

Intervjuu Tiia Lõokesega 30. aprillil 2012.

Tiia Lõokese kirjalik teade 1. mail 2012.

Intervjuu Taivo Oruga 15. märtsil 2012.

Intervjuu Saddhalokaga 15. märtsil 2012.

Intervjuu Saddhalokaga 13. aprillil 2012.

Intervjuu Sarvamitraga 19. aprillil 2012.

Intervjuu Vaddhakaga 7. märtsil 2012.

Intervjuu Dharmachari Vaddhakaga 4. aprillil 2012.

Intervjuu materjalid ja kirjalikud teated on hoiul autori käes.

\section{Kirjandus}

Altnurme, Lea 2006. Kristlusest oma usuni. Uurimus muutustest eestlaste religioossuses 20. saj II poolel. Tartu: Tartu Ülikooli kirjastus.

Batchelor, Stephen1994. The Awakening of the West. The Encounter of Buddhism and Western Culture. Parralax Press.

Baumann, Martin 2006a. Friends of the Western Buddist Order. Clarke, Peter B. (toim). Encyclopedia of New Religious Movements. New York: Routledge, lk 197-198.

Baumann, Martin 2006b. Sangharakshita. Clarke, Peter B. (toim). Encyclopedia of New Religious Movements. New York: Routledge, lk 500-501.

Bielefeldt, Carl 2005. Practice. Lopez, Donald jr. (toim). Critical Terms for the Study of Buddhism. Chicago: University of Chicago Press, lk 229-244.

Kamalašila 1995. Mõtlus: tee meelerahu ja ületava mõistmiseni. Helsinki: FWBO.

Liiders, Lauri 2012a. Budism uususundina Eestis Triratna Budistliku Kogukonna näitel. Magistritöö. Tartu: Tartu Ülikooli usuteaduskond.

Liiders, Lauri 2012b. Triratna Budistlik Kogukond. Altnurme, Lea (koost). Uued usulised ja vaimsed ühendused Eestis. Tartu: Tartu Ülikooli kirjastus, lk 60-66. 
Lopez, Donald. 2002. An introduction. Modern Buddhism: Readings for the Unenlightened. London: Penguin Books, lk 186-187.

Morrison, Robert 2006. Friends of the Western Buddist Order. Partridge, Christopher (toim). Encyclopedia of New Religions. New Religious Movements, Sects and Alternative Spiritualitie. Oxford: Lion Books, lk 193-195.

Preem, Britt-Maria \& Põlenik, Ave 2001. Budistlikud kogudused Eestis 1984-2001. Bakalaureusetöö. Tartu: Tartu Ülikooli usuteaduskond.

Põlenik, Ave 2004. Budismist Eestis. Altnurme, Lea (koost ja toim). Mitut usku Eesti: valik usundiloolisi uurimusi. Tartu: Tartu Ülikooli kirjastus, lk 67-95.

Rawlinson, Andrew 1998. The Book of Enlightened Masters. Western Teachers in Eastern Traditions. Chicago \& La Salle: Open Court.

Ringvee, Ringo 2000. Religions in Estonia. Kaplan, Jeffrey (toim). Beyond the Mainstream: the Emergence of Religious Pluralism in Finland, Estonia and Russia. Helsinki: SKS, lk 107-116.

Sangharakshita 1990. New Currents in Western Buddhism. The Inner Meaning of the Friends of the Western Buddhist Order. Windhorse Publications (http://www.sangharakshita.org/_books/new-currents.pdf - 21. märts 2013).

Vajragupta 2011. The Triratna Story. Cambridge: Windhorse Publications (http://thebuddhistcentre.com/timeline/the-triratna-story-by-vajragupta.pdf - 21. märts 2013).

\section{SUMMARY}

\section{Triratna Buddhist Community: Case Study of a Buddhist Congregation in Estonia}

\section{Lauri Liiders}

Keywords: Buddhism, Estonia, religious practices, religious studies

This paper provides an overview of the first detailed case study of a Buddhist congregation in Estonia. The object of this study is Triratna Buddhist Community in Estonia, which was established here in 1989 and is part of international Triratna Buddhist Community (formerly known as Friends of the Western Buddhist Order) created in the United Kingdom in 1967. Mainly through oral history and participant observation methods as well as analysis of data presented by different written and oral sources the researcher strives to give an overview of various aspects of activity connected with one particular Buddhist group in Estonia, including its practice, ordination rituals, beliefs and membership characteristics. It also includes a detailed overview of the congregation's history and its relationship with members of Triratna congregations in Finland and the UK. It presents Buddhism as an emerging new religion in Estonia through a case study of a Western Buddhist ecumenical congregation. 